\title{
Dendrosomal curcumin nanoformulation downregulates pluripotency genes via miR-/ 45 activation in U87MG glioblastoma cells
}

This article was published in the following Dove Press journal:

International Journal of Nanomedicine

13 January 2014

Number of times this article has been viewed

\author{
Maryam Tahmasebi Mirgani' \\ Benedetta Isacchi \\ Majid Sadeghizadeh ${ }^{1, *}$ \\ Fabio Marra ${ }^{3}$ \\ Anna Rita Bilia 2,* \\ Seyed Javad Mowla' \\ Farhood Najafi ${ }^{4}$ \\ Esmael Babaei ${ }^{5}$ \\ 'Department of Genetics, Tarbiat \\ Modares University, Tehran, Iran; \\ ${ }^{2}$ Department of Chemistry, University \\ of Florence, Sesto Fiorentino, Italy; \\ ${ }^{3}$ Department of Experimental and \\ Clinical Medicine, University of \\ Florence, Italy; ${ }^{4}$ Department of Resin \\ and Additives, Institute for Color \\ Science and Technology, Tehran, Iran; \\ ${ }^{5}$ Department of Biology, University \\ of Tabriz, Tabriz, Iran \\ *These authors contributed equally to \\ this work
}

Correspondence: Majid Sadeghizadeh Tarbiat Modares University, Faculty of Bioscience, Department of Molecular Genetics, Jalal Ale Ahmad Highway, PO Box I4II5-III, Tehran, Iran Tel +982182884409

Fax +98 2I 88007598

Email sadeghma@modares.ac.ir

\begin{abstract}
Glioblastoma is an invasive tumor of the central nervous system. Tumor recurrence resulting from ineffective current treatments, mainly due to the blood-brain barrier, highlights the need for innovative therapeutic alternatives. The recent availability of nanotechnology represents a novel targeted strategy in cancer therapy. Natural products have received considerable attention for cancer therapy because of general lower side effects. Curcumin is a new candidate for anticancer treatment, but its low bioavailability and water solubility represent the main disadvantages of its use. Here, curcumin was efficiently encapsulated in a nontoxic nanocarrier, termed dendrosome, to overcome these problems. Dendrosomal curcumin was prepared as $142 \mathrm{~nm}$ spherical structures with constant physical and chemical stability. The inhibitory role of dendrosomal curcumin on the proliferation of U87MG cells, a cellular model of glioblastoma, was evaluated by considering master genes of pluripotency and regulatory miRNA (microribonucleic acid). Methylthiazol tetrazolium assay and flow cytometry were used to detect the antiproliferative effects of dendrosomal curcumin. Annexin-V-FLUOS and caspase assay were used to quantify apoptosis. Real-time polymerase chain reaction was used to analyze the expression of OCT4 (octamer binding protein 4) gene variants (OCT4A, OCT4B, and OCT4B1), SOX-2 (SRY [sex determining region Y]-box 2), Nanog, and miR-145. Dendrosomal curcumin efficiently suppresses U87MG cells growth with no cytotoxicity related to dendrosome. Additionally, the accumulation of cells in the SubG phase was observed in a time- and dose-dependent manner as well as higher rates of apoptosis after dendrosomal curcumin treatment. Conversely, nonneoplastic cells were not affected by this formulation. Dendrosomal curcumin significantly decreased the relative expression of $O C T 4 A$, $O C T 4 B 1, S O X-2$, and Nanog along with noticeable overexpression of miR-145 as the upstream regulator. This suggests that dendrosomal curcumin reduces the proliferation of U87MG cells through the downregulation of OCT4 (octamer binding protein 4) variants and SOX-2 (SRY [sex determining region Y]-box 2) in an miR-145-dependent manner.
\end{abstract}

Keywords: glioblastoma, pluripotency gene, miRNA, dendrosomal curcumin

\section{Introduction}

Glioblastoma is characterized by a high potential for growth and invasion. Insensitivity of this tumor to general therapies, including radio- and chemotherapy, leads to a high rate of recurrence. Until now, little was known about the genetic mechanisms involved in gliomagenesis. ${ }^{1-4}$ A positive association between the overexpression of stem cell marker genes and progression/metastasis of tumors triggered the idea that targeting of self-renewal pathways can be applied as a powerful approach in cancer treatment. ${ }^{5}$ Transcription factors, OCT4 (octamer binding protein 4), SOX-2 (SRY [sex determining region Y]-box 2), and Nanog play crucial roles in the maintenance of stemness in both embryonic and somatic stem cells. ${ }^{6}$ Several studies have reported the oncogenic 
role of these transcription factors in glioblastoma cells..$^{2,3,7,8}$ Regulation of these pluripotency factors is under the control of a subset of micro ribonucleic acids (miRNAs), which are favorably expressed in undifferentiated stem cells. The promoter regions of these miRNAs and pluripotency factors are implicated in a precise reciprocal interaction giving rise to cell pluripotency or differentiation. ${ }^{6} \mathrm{miR}-145$ is well understood in stemness pathways. It has been demonstrated that $m i R-145$ induces differentiation in stem cells by suppressing the promoter of OCT4 and SOX-2.9,10 This explains the cause of low level miR-145 expression in most cancers. ${ }^{11}$ There is a considerable attention to replacing the chemical anticancer treatment agents with plant-based formulations to mitigate the undesirable effects during the prolonged treatment of patients. Curcumin is a hydrophobic compound extracted from the rhizome of Curcuma longa, which is employed as a spice and coloring agent in most Asian countries. A growing body of evidence has substantiated the antitumor properties of curcumin in various cancer cells through interaction with multiple signaling pathways. ${ }^{12-15}$ However, low water solubility, poor uptake and tissue distribution remain major obstacles, limiting the use of curcumin as an anticancer treatment agent. ${ }^{16}$ Recently, scientists have revealed several strategies, such as loading synthetic analogs from turmeric, designing metabolic inhibitors and liposomal formulations, and nanoparticles of curcumin, to overcome these problems. ${ }^{17-20}$ Dendrosome was introduced as a novel neutral, amphipathic, and biodegradable nanocarrier for a gene delivery system in the authors' research group. ${ }^{21,22}$ The high potential of dendrosome as a gene porter led to the hypothesis that it can be exploited as a vehicle for curcumin delivery. The anticancer properties of dendrosomal curcumin (DNC) have been explored in mice models of fibrosarcoma and colon cancer. ${ }^{21-24}$ It was demonstrated that dendrosome improves the solubility of curcumin and facilitates its uptake by cancer cells, suggesting that this polymer could open new avenues for successful drug delivery in cancer therapy. ${ }^{23,24}$ The present study reports for the first time a full characterization of DNC and describes the underlying mechanism through which curcumin targets the pluripotency pathways of glioblastoma cancer cells. U87MG - a cellular model of grade IV glioblastoma - was used in this regard. The probable cytotoxicity of this formulation on normal stem cells and fibroblast cells was also evaluated to determine if DNC can be considered a safe preparation for use in clinical and pharmaceutical approaches.

\section{Material and methods Chemicals and standards}

Curcumin was purchased from Merck KGaA (Darmstadt, Germany) with purity of $95 \%$. Materials for the preparation of dendrosome were oleoyl chloride and polyethylene glycol 400 that was purchased from Sigma-Aldrich (St Louis, MO, USA), and chloroform and triethyl amine were purchased from Merck. All the solvents used were high-performance liquid chromatography (HPLC) grade from Merck; 85\% formic acid was provided by Carlo Erba Reagents (Cornaredo, Italy). Water was purified by a Milli-Q ${ }^{\circledR}$ Plus system from EMD Millipore (Billerica, MA, USA). Phosphate-buffered saline (PBS) solution was from Sigma-Aldrich. Curcumin reference standard $(10 \mathrm{mg})$ was provided by Extrasynthese (Genay Cedex, France).

\section{Polymeric micelle OA400 carrier (dendrosome) preparation}

\section{Synthesis of dendrosome}

The OA400 carrier was synthesized by esterification of oleoyl chloride $(0.01 \mathrm{~mol})$ and polyethylene glycol $400(0.01 \mathrm{~mol})$ in the presence of triethyl amine $(0.012 \mathrm{~mol})$ and chloroform as the solvent at $25^{\circ} \mathrm{C}$ for 4 hours. Triethylamine hydrochloride salt was filtered from its organic phase. Then, chloroform was evaporated from OA400 in vacuum oven at $40^{\circ} \mathrm{C}$ for 4 hours (Figure 1). Fourier transform infrared spectroscopy (Spectrum One, PerkinElmer, Inc., Shelton, CT, USA) analysis was

$$
\begin{gathered}
\mathrm{H}_{3} \mathrm{C}-\left(\mathrm{CH}_{2}\right)_{7}-\underset{\mathrm{H}}{\mathrm{C}}=\underset{\mathrm{H}}{\mathrm{C}}-\left(\mathrm{CH}_{2}\right)_{7}-\stackrel{\mathrm{O}}{\mathrm{C}}-\mathrm{Cl}+\mathrm{H}-\left(\mathrm{OCHCH}_{2}\right) \mathrm{n}-\mathrm{OH} \\
\text { PEG } 400
\end{gathered}
$$

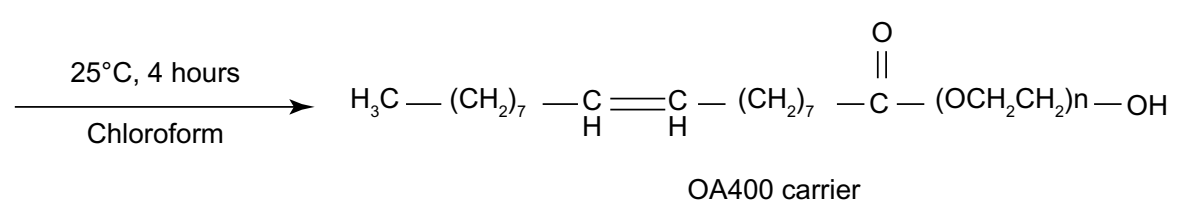

Figure I Synthesis of the OA400 carrier. Abbreviation: PEG, polyethylene glycol. 
performed to confirm the dendrosomal chemical structure. The Fourier transform infrared spectrum of OA400 shows a stretching band of $\mathrm{C}-\mathrm{H}$ aliphatic at $2,921 \mathrm{~cm}^{-1}$, a stretching band of $\mathrm{C}-\mathrm{H}$ unsaturated aliphatic at $3,002 \mathrm{~cm}^{-1}$, and a stretching band carbonyl group of ester bands at $1,732 \mathrm{~cm}^{-1}$. The $\mathrm{C}-\mathrm{H}$ bending vibration of $\mathrm{CH}_{2}$ and the $\mathrm{C}-\mathrm{H}$ bending vibration of $\mathrm{CH}_{3}$ can be seen at 1,462 $\mathrm{cm}^{-1}$ and $1,350 \mathrm{~cm}^{-1}$, respectively. The $\mathrm{C}-\mathrm{O}$ stretching vibration was at $1,111 \mathrm{~cm}^{-1}$ as a broad band. The $\mathrm{C}=\mathrm{C}$ stretching vibration can be seen at $1,651 \mathrm{~cm}^{-1}$ (Figure $\mathrm{S} 1$ ).

\section{Preparation of the DNC}

DNC preparation was performed using optimized protocol in the authors' lab. ${ }^{23}$ Briefly, different weight/weight ratios of dendrosome/curcumin ranging from 50:1 to 10:1 were examined before settling on a suitable ratio of 25:1. Curcumin was dissolved in various amounts of dendrosome and checked for absorbance spectra by ultraviolet spectrophotometry (Infinite ${ }^{\circledR} 200$ PRO, Tecan, Mannedorf, Switzerland). Then, the appropriate mixture of dendrosome and curcumin was evaluated for excitation/emission value in comparison with curcumin dissolved in PBS and 1\% methanol as the control samples. ${ }^{23}$ The loading of dendrosome nanocarriers with curcumin molecules was performed using Gou et al's protocol. ${ }^{25}$ Briefly, curcumin and dendrosome were co-dissolved in $5 \mathrm{~mL}$ acetone; this solution was added into $5 \mathrm{~mL}$ PBS while stirring constantly. Then, the acetone was evaporated in a rotary evaporator. The curcumin/dendrosome micelle solution was sterilized using a $0.22 \mu \mathrm{m}$ syringe filter (EMD Millipore). ${ }^{25}$ Finally, the prepared DNC were stored at $4{ }^{\circ} \mathrm{C}$ in a light-protected condition until used. ${ }^{23}$ For in vitro experiments, DNC was diluted in complete culture medium.

\section{In vitro characterization}

\section{Particle characterization of the dendrosomal} formulation

DNC particle size was measured by dynamic light scattering (DLS) (Zetasizer ${ }^{\circledR}$ Nano ZS90; Malvern Instruments, Malvern, UK). Time correlation functions were analyzed to obtain the hydrodynamic diameter of the particles and the particle size distribution (polydispersity index [PDI]) using ALV-60X0 software V.3.X (Malvern). Autocorrelation functions were analyzed by the cumulant method fitting a single exponential to the correlation function to obtain the mean size, PDI, and distribution method (to fit a multiple exponential to the correlation function to obtain particle size distributions). Scattering was measured in an optical quality $4 \mathrm{~mL}$ borosilicate cell at a 90 -degree angle. For these measurements, $20 \mu \mathrm{L}$ DNC dispersion was diluted 100 -fold with $\mathrm{PBS}$. Measurements were carried out at the set temperature of $25^{\circ} \mathrm{C}$.

\section{Electrophoretic mobility}

The superficial charge ( $\zeta$-potentials) of the DNC systems was measured using a Zetasizer Nano ZS90 (Malvern). For all samples, an average of three measurements at the stationary level was taken. The temperature was kept constant at $25^{\circ} \mathrm{C}$ by a temperature controller. The $\zeta$-potential was calculated from the electrophoretic mobility $\left(\mu_{\mathrm{E}}\right)$ using the Henry correction to Smoluchowski's equation.

\section{Encapsulation efficacy}

Free curcumin were removed by means of dialysis. DNC was transferred in a dialysis bag. This dialysis bag was stirred in $360 \mathrm{~mL}$ PBS at room temperature for 2 hours. The aqueous medium was refreshed once. The content of curcumin into the dendrosome was quantified by HPLC with diode array detection (HPLC-DAD) analysis, using curcumin as an external standard. The curcumin encapsulation yield is expressed as the so-called encapsulation efficiency (EE), which is defined as the percentage amount of curcumin entrapped in the dendrosome in relation to the total amount of curcumin present during the DNC formation and entrapment procedure.

The curcumin-loaded concentration was assayed by HPLCDAD analysis performed using the HP 1100 equipped with an HP 1040 DAD, an automatic injector, an auto sampler, and a column oven, and managed by the HP 9000 workstation (Agilent Technologies, Santa Clara, CA, USA). The ultravioletvisible spectra were recorded between $220-500 \mathrm{~nm}$ and the chromatographic profiles were registered at 240, 330, 420, and $430 \mathrm{~nm}$. Separations were performed on a reversed-phase column Luna ${ }^{\circledR}$ RP C18 (150 mm $\times 3$ mm id, $5 \mu \mathrm{m}$; Phenomenex, Torrance, CA, USA) maintained at $26^{\circ} \mathrm{C}$. The eluents were $\mathrm{H}_{2} \mathrm{O}$ at $\mathrm{pH} 3.2$ by formic acid (A) and acetonitrile (B). The following multistep linear gradient was applied: from $82 \% \mathrm{~A}$ to $56 \% \mathrm{~A}$ in 10 minutes, with a plateau of 3 minutes, in 14 minutes to $48 \% \mathrm{~B}$, and then 5 minutes to $80 \%$ of $\mathrm{B}$. Total time of analysis was 32 minutes, equilibration time was 5 minutes, flow rate was $0.4 \mathrm{~mL} \cdot \mathrm{min}^{-1}$, and injection volume was $5 \mu \mathrm{L}$.

\section{Transmission electron microscopy analysis}

A drop $(10 \mu \mathrm{L})$ of DNC dispersion diluted ten times was applied to a carbon film-covered copper grid (Società Italiana Chimici, Rome, Italy). Most of the dispersion was blotted from the grid with filter paper to form a thin film specimen, which was stained with a phosphotungstic acid solution $1 \%$ 
weight/volume in sterile water. The samples were dried for 3 minutes and then examined under a JEOL 1010 electron microscope (JEOL, Tokyo, Japan) and photographed at an accelerating voltage of $64 \mathrm{kV}$.

\section{Stability studies}

The stability of DNC was studied according to the authors' previous work. ${ }^{26,27} \mathrm{DNC}$ was kept at $4{ }^{\circ} \mathrm{C} \pm 1^{\circ} \mathrm{C}$, and at fixed time intervals they were assayed for their physical and chemical stability. Physical stability was checked by monitoring the size and PDI using DLS measurements. Chemical stability was checked by quantification of drug content after disruption of purified vesicles using HPLC-DAD analysis.

\section{In vitro assessment of the anticancer effect of DNC}

\section{Cell lines and culture condition}

Glioblastoma cancer cell lines (U87MG), human bone marrow-derived stem cells (hBMSC), and normal human fibroblastic cells (HFSF-PI3) were obtained from the national cell bank of the Pasteur Institute, Tehran, Iran. U87MG, hBMSC, and HFSF-PI3 cells were cultured in Gibco ${ }^{\circledR}$ RPMI 1640 medium and Gibco ${ }^{\circledR}$ low and high glucose Dulbecco's Modified Eagle Medium (Life Technologies, Carlsbad, CA, USA), respectively. Cells were supplemented with $10 \%$ fetal bovine serum, $100 \mathrm{U} / \mathrm{mL}$ penicillin, and $100 \mathrm{mg} / \mathrm{mL}$ streptomycin (Life Technologies). All cells were grown at $37^{\circ} \mathrm{C}$ in a humidified atmosphere of 5\% carbon dioxide.

\section{Cell viability assay}

Cell viability was assessed by methylthiazol tetrazolium (MTT) assay (Sigma-Aldrich) according to the manufacturer's instruction. Briefly, cells were plated onto 96-well plates, respectively. After 24 hours, the cells were incubated for 24,48 , and 72 hours in the absence or presence of different concentrations of DNC. Dendrosome alone was used to test the cytotoxicity of the nanocarriers. After the treatment, media containing the treatment agents were carefully removed and cells were washed twice with PBS before $20 \mu \mathrm{L}$ medium containing $5 \mathrm{mg} / \mathrm{mL}$ MTT in PBS was added to each well. After 4 hours at $37^{\circ} \mathrm{C}$, the medium was totally removed and $200 \mu \mathrm{L}$ dimethyl sulfoxide solution was added to each well. The absorbance being proportional to cell viability was subsequently measured at $570 \mathrm{~nm}$ in each well using an enzyme-linked immunosorbent assay plate reader. All values were compared to the corresponding controls. Cell viability was calculated as the percentage of cell viability of treated cells against control cells.

\section{Cell cycle analysis}

The effect of DNC on cell cycle distribution was assessed by flow cytometry after staining the cells with propidium iodide (PI). Briefly, $0.3 \times 10^{6}$ cells (U87MG) were seeded onto six-well plates and allowed to attach overnight. The previous medium was replaced with a fresh one containing the desired concentrations of DNC. After incubating for specified times, cells were collected and washed twice with cold PBS and fixed with ice-cold $70 \%$ ethanol at $4{ }^{\circ} \mathrm{C}$ overnight. After washing twice with cold PBS, cells were resuspended in PBS containing $50 \mu \mathrm{g} / \mathrm{mL}$ PI, $0.1 \%$ sodium citrate, and 0.1 Triton $\mathrm{X}-100$ followed by shaking at $37^{\circ} \mathrm{C}$ for 15 minutes. More than $10^{4}$ cells were analyzed using a FACSCalibur ${ }^{\mathrm{TM}}$ flow cytometer (BD Biosciences, San Jose, CA, USA) and the data were consequently evaluated using Cell Quest software (BD Biosciences). Cells with a lower DNA content than those of the $\mathrm{G}_{0} / \mathrm{G}_{1}$ phase were referred to as apoptotic cells. The percentage of cells in each phase of the cell cycle was determined by at least three independent tests and the results were expressed as mean \pm standard deviation.

\section{Apoptosis detection}

Annexin-V-FLUOS and PI staining kit (Roche Applied Science, Penzberg, Germany) was used for apoptosis detection following the manufacturer's instruction. Briefly, U87MG cells were seeded $\left(0.3 \times 10^{6}\right.$ cells/well $)$ onto sixwell plates and allowed to adhere overnight to be treated with desired concentrations of DNC for 12, 24, and 36 hours. Trypsin-digested cells were centrifuged at $200 \mathrm{~g}$ for 5 minutes. The cell pellet was resuspended in $100 \mu \mathrm{L}$ Annexin-V-FLUOS labeling solution and incubated for $10-15$ minutes at $15^{\circ} \mathrm{C}-20^{\circ} \mathrm{C}$ and immediately analyzed by FACSCalibur flow cytometer.

\section{Caspase activity}

Caspase activity was measured by the homogeneous caspase assay kit (Roche) according to manufacturer's instructions. Enzymatic activity of caspase-2, 3, 6, 7, 8, 9, and 10 were determined using this assay. Cells were cultured onto 96-well plates $\left(2 \times 10^{4}\right.$ cell/well $)$ and treated with various concentrations of DNC at different intervals. The amount of free rhodamine 110 resulting from cleavage of the caspase substrate (DEVD-rhodamine 110) was fluorometrically determined at an excitation and emission wavelength of $499 \mathrm{~nm}$ and $521 \mathrm{~nm}$, respectively. Data were expressed as relative fluorescence units by Gene 5 software with a fluorescence plate reader (Synergy ${ }^{\text {TM }}$ H4 Hybrid Reader; 
BioTek, Winooski, VT, USA). Three independent tests were performed and the ratio between the treatment and control group was calculated. Data were expressed as mean \pm standard deviation.

\section{RNA extraction and real-time polymerase chain reaction (PCR)}

Total RNA was extracted using TRIzol ${ }^{\circledR}$ reagent (Life Technologies) followed by DNase I digestion (Thermo Fisher Scientific, Waltham, MA, USA). Complementary DNA was synthesized by PrimeScript ${ }^{\mathrm{TM}}$ RT reagent kit (Takara Bio Inc, Shiga, Japan). The list of primers for specific genes and housekeeping gene glyceraldehyde 3-phosphate dehydrogenase (GAPDH) are indicated in Table 1. Real-time PCR was performed using the SYBR ${ }^{\circledR}$ Premix Ex Taq ${ }^{\mathrm{TM}}$ II (Takara). Relative gene expression was calculated as $2^{-\Delta \Delta \mathrm{Ct}}$.

\section{miRNA expression analysis}

The expression of miR-145 and U6 (reference gene) was analyzed using universal specific primer sets and miRCURY LNA $^{\mathrm{TM}}$ Universal RT microRNA PCR (Exiqon A/S, Vedbaek, Denmark).

\section{Statistical analysis}

Statistics were presented in Prism ${ }^{\circledR} 5$ software (GraphPad Software, Inc, La Jolla, CA, USA) and analyzed using oneway analysis of variance followed by Newman-Keuls multiple comparison test or Student's $t$-test. Differences among groups were stated to be statistically significant when $P<0.05$.

Table I List of the sets of primers for specific genes or for the housekeeping gene, GAPDH, used in real-time polymerase chain reaction assay

\begin{tabular}{|c|c|c|}
\hline Gene & Designed oligonucleotide & $\begin{array}{l}\text { Amplicon } \\
\text { length } \\
\text { (bp) }\end{array}$ \\
\hline \multirow[t]{2}{*}{ OCT4A } & F: TCGCAAGCCCTCATTTC & 113 \\
\hline & R: CCATCACСТCCACCACCT & \\
\hline \multirow[t]{2}{*}{ OCT4B } & F: AGATTGATAACTGGTGTGTTTATGTTC & 191 \\
\hline & R: GCTGAATACCTTCCCAAATAGAAC & \\
\hline \multirow[t]{2}{*}{ OCT4BI } & F: GGTTCTATTTGGTGGGTTCC & 130 \\
\hline & R: TTCTCССТСТСССТАСТССТC & \\
\hline \multirow[t]{2}{*}{ SOX-2 } & F: AAGACTAGGACTGAGAGAAAGAAGAG & $17 \mid$ \\
\hline & R: AAGAGAGAGGCAAACTGGAATC & \\
\hline \multirow[t]{2}{*}{ Nanog } & F: AATACCTCAGCCTCCAGCAGATG & 148 \\
\hline & R: TGCGTCACACCATTGCTATTCTTC & \\
\hline \multirow[t]{2}{*}{ GAPDH } & F: GTGAACCATGAGAAGTATGACAAC & \\
\hline & R: CATGAGTCCTTCCACGATACC & 123 \\
\hline
\end{tabular}

Abbreviations: $F$, forward primer; $R$, reverse primer; $G A P D H$, glyceraldehyde 3-phosphate dehydrogenase; OCT4, octamer binding protein 4; SOX-2, SRY (sex determining region Y)-box 2.

\section{Results}

\section{In vitro characterization of DNC formulation}

Dimensional analysis, superficial charge, and loading efficiency of DNC

DNC was analyzed in terms of size, PDI, and $\zeta$-potential measured by DLS analysis and in terms of encapsulation efficacy by HPLC-DAD analysis. Regarding DLS measurements, correlation coefficients were superior to 0.9, which means that the signal related to noise ratio was good (10\%) (Figure 2A). The mean diameter of DNC was $\leq 200 \mathrm{~nm}$ by distribution algorithm-calculated DLS analysis (Figure 2B and D), and was suitable for systemic administration. PDI is a dimensionless measurement of the broadness size distribution calculated from distribution algorithm, and values were calculated for each peak as peak width/mean diameter. As summarized in Figure 2D, PDI was 0.4; therefore, the colloidal suspension of DNC was polydispersed. The measurements performed three times were nicely reproducible. The $\zeta$-potential was around $-7 \mathrm{mV}$, an acceptable value that does not indicate long-term stability. The curcumin loading efficiency was very high (87\%). Transmission electron micrographs by positive stain provided important details on the morphology and dimension of the vesicles. DNC were sphere shaped and had a size comparable with the results from DLS analysis (Figure 2C) considering the different physical principles the two techniques were based on.

\section{Physical and chemical stability tests of DNC}

The physical stability of DNC was checked by monitoring size and PDI over time using DLS measurements. Size was maintained within 10 days (Figure 3A), and although PDI increased to 0.6 at day 16, it was constant within 10 days after DNC preparation (0.4). According to these results, no vesicle size alterations or homogeneity loss of the sample occurred within 10 days (Figure 3A). Additionally, chemical stability was checked by quantification of drug content after disruption of purified vesicles. As described in the experimental section, the content of curcumin into the dendrosome was quantified by HPLC-DAD analysis. The chemical stability of curcumin into the dendrosome was maintained at a constant level (not less than 93.8\% residual percentage) at least 16 days after their preparation (Figure 3B). Both physical and chemical stabilities (in terms of residual percentage of drug) were acceptable for 10 days. 
A

\section{Raw correlation data}

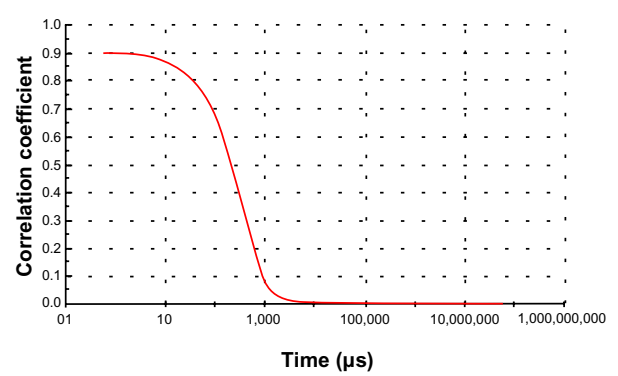

C
B

Size distribution by intensity
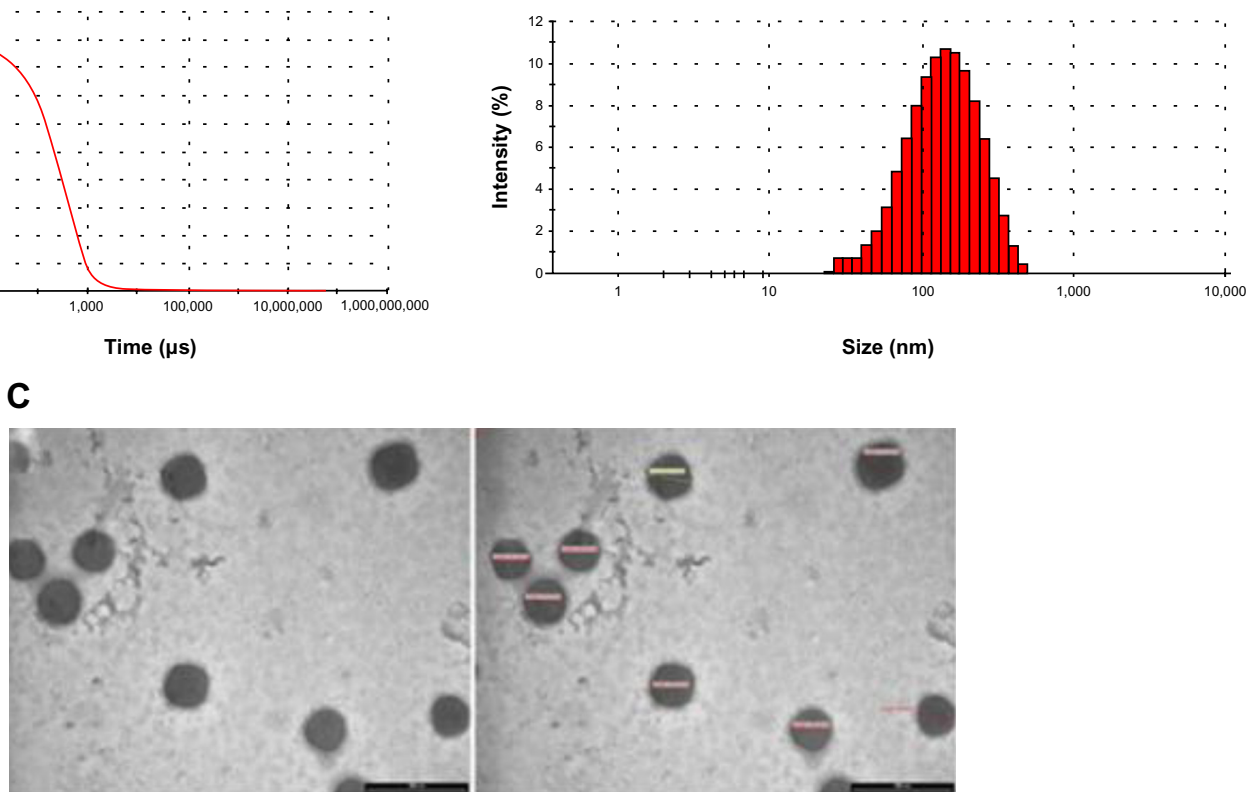

Size (nm)

D

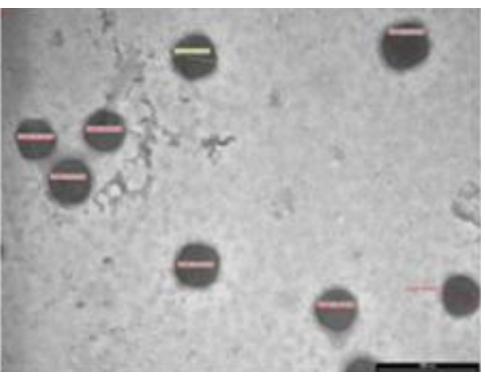

\begin{tabular}{|c|c|c|c|}
\hline $\begin{array}{c}\text { Size } \\
(\mathrm{nm})\end{array}$ & PDI & $\begin{array}{c}\zeta \text {-potential } \\
(\mathrm{mV})\end{array}$ & $\begin{array}{c}\mathrm{EE} \\
(\%)\end{array}$ \\
\hline $142.97 \pm 4.27$ & $0.4 \pm 0.03$ & $-7.81 \pm 1.40$ & $87.65 \pm 1.82$ \\
\hline
\end{tabular}

Figure 2 (A) Autocorrelation function. (B) Particle size distribution as a function of intensity (\%) obtained by dynamic light scattering of dendrosomal curcumin. (C) Dendrosomal curcumin in transmission electron micrographs. (D) Size, polydispersity index, $\zeta$-potential, and encapsulation efficiency of dendrosomal curcumin. Data expressed as mean \pm standard deviation.

Abbreviations: $\mathrm{EE}$, encapsulation efficiency; PDI, polydispersity index.

\section{In vitro assessment of anticancer effect of DNC}

\section{DNC induces cell death in U87MG}

\section{in a time- and dose-dependent manner}

The sensitivity of U87MG cells as well as hBMSC and HFSFPI3 cells to DNC, free curcumin, and empty dendrosome were studied using MTT assay. As shown in Figure 4, DNC significantly suppressed the proliferation of U87MG cells in a time- and dose dependent manner. The half maximal inhibitory concentration $\left(\mathrm{IC}_{50}\right)$ of DNC for U87MG cells was $20 \mu \mathrm{M}$ after 24 hours (Figure 4A) and 48 hours (Figure 4B), which declined to $10 \mu \mathrm{M}$ at 72 hours (Figure $4 \mathrm{C})(P<0.001)$. However, the viability of U87MG was not affected by free curcumin only at 72 hours (Figure 4C). On the other hand, no inhibitory effect was observed for dendrosome alone. In total, these findings demonstrate that dendrosome increased the water solubility and entry of curcumin to cells without any toxic effects correlated with dendrosomes as a carrier. Studying the inhibitory effects of DNC on hBMSC showed that these cells are affected by DNC as well as cancerous cells and in a concentration higher than in U87MG cells. Figure 5A shows the effects of DNC on cell viability of hBMSC after 24 hours of drug exposure. Cell viability declined to $67 \%$ after treatment with $25 \mu \mathrm{M}$ DNC $(P<0.01)$ and to $35 \%$ and $31 \%$ after treatment with $30 \mu \mathrm{M}$ and $35 \mu \mathrm{M}$ DNC, respectively $(P<0.001)$. The loss of cell viability was also determined after 48 hours of treatment with DNC (Figure 5B). The cell viability declined to $54 \%$ and $52 \%$ after treatment with $30 \mu \mathrm{M}$ and $35 \mu \mathrm{M} \mathrm{DNC}$, respectively $(P<0.05)$. The viability of HFSF-PI3 was not significantly affected due to treatment and at determined $\mathrm{IC}_{50}$ for U87MG lines, no inhibitory effect was detected on these cells $(P>0.05)$; however, at $25 \mu \mathrm{M}$ concentration, the viability of the cells decreased to $50 \%$ (Figure 6$)(P<0.01)$. Therefore, in concentrations suppressive for cancer cells, no harmful effects connected to DNC were observed in stem cells and normal fibroblast cells, showing the safety of this formulation as an anticancer treatment agent on normal cells.

\section{The effects of DNC on the U87MG cell cycle distribution}

To achieve further insight into the mechanism of the growth inhibitory effects of DNC, U87MG cells were treated in con- 

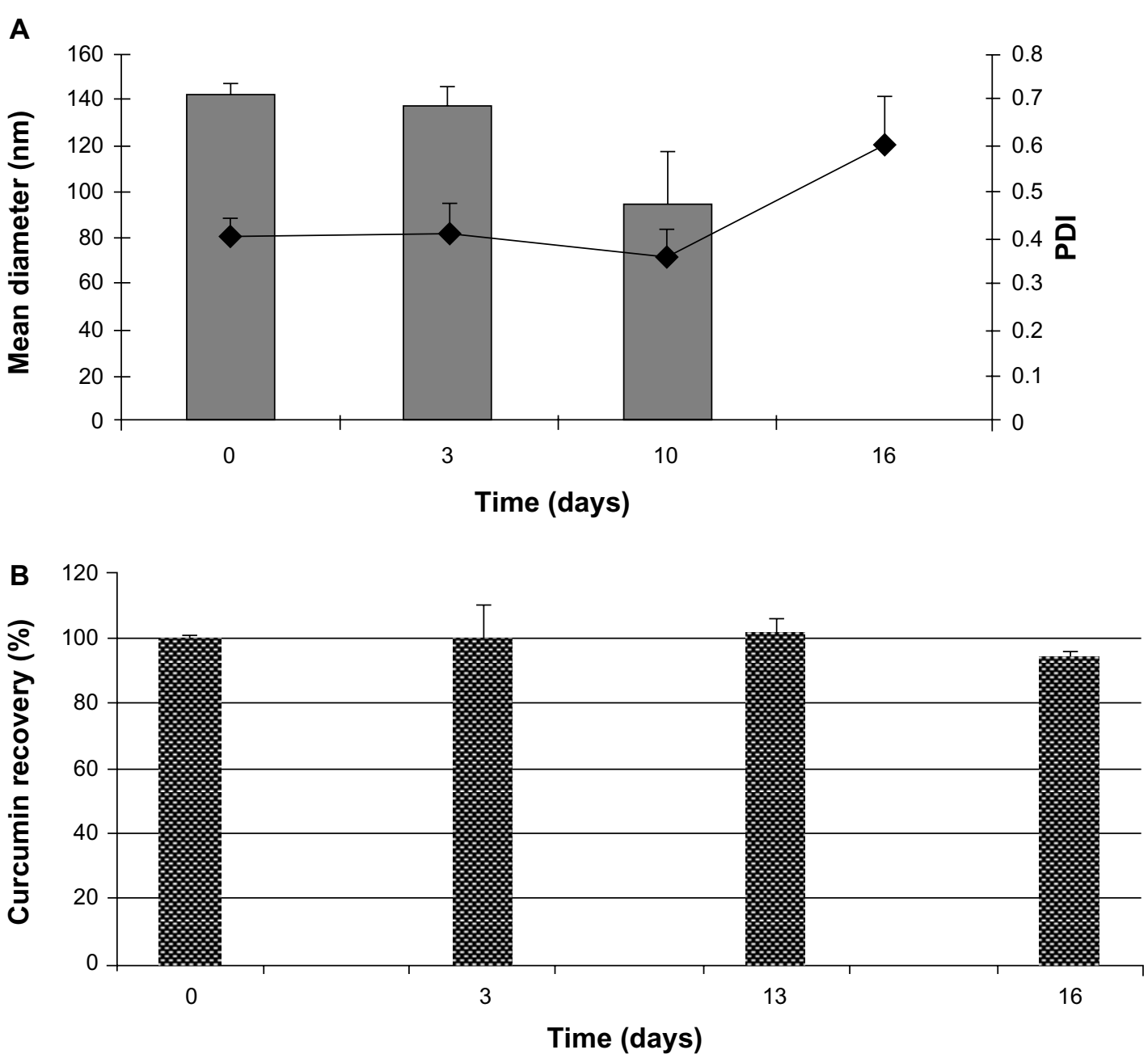

Figure 3 (A) Physical stability of dendrosomal curcumin in terms of mean diameter (nm), polydispersity index, and dynamic light scattering analysis. (B) Chemical stability of dendrosomal curcumin in terms of curcumin content (recovery \%) by high-performance liquid chromatography with diode-array detection analysis.

Note: Data expressed as mean \pm standard deviation.

Abbreviation: PDI, polydispersity index.

centrations close to the $\mathrm{IC}_{50}(15,17.5$, and $20 \mu \mathrm{M})$ obtained in the MTT assay. Treated cells analyzed for cell cycle distribution were compared to the control. By increasing the concentration of DNC at 24 hours of treatment, the cell population in the $\mathrm{SubG}_{1}$ phase significantly increased $(P=0.0006)$. Cells in the $\mathrm{G}_{1}$ or $\mathrm{S}$ phase gradually decreased, but not at a statistically significant rate $\left(\mathrm{G}_{1}: P=0.06 ; \mathrm{S}: P=0.3\right)$. Surprisingly, cells in the $\mathrm{G}_{2} / \mathrm{M}$ phase were significantly reduced $(P=0.0147)$, consistent with the fact that DNC can target the cell division and proliferation pathways (Figure 7A-C and Table 2). By increasing the time of treatment to 36 hours, an increased cell death rate in the SubG ${ }_{1}$ phase $(P=0.0036)$ together with a gradual decrease in the $\mathrm{G}_{1}$ phase $(P=0.0029)$ showed that enhancing the incubation time resulted in probable inhibition of the cell growth pathway (Figure 8). Increasing incubation time from 12 hours to 24 hours led to a significant increase in the $\mathrm{SubG}_{1}$ cell population $(P=0.0215)$. However, the rate of cell death slightly decreased at 36 hours compared with 24 hours (Figure 7D, E and Table 3). The cell population in the $\mathrm{G}_{2} / \mathrm{M}$ and $\mathrm{S}$ phases decreased, although these changes were not significant (data not shown). Altogether, these data show that DNC induced cell death in a time- and dose-dependent manner in U87MG cells.

\section{DNC triggers apoptosis in U87MG cells}

To determine the mode of cell death (apoptosis or necrosis) induced by DNC, Annexin-V-FLUOS and PI staining were applied to separate intact cells, early apoptosis, late apoptosis, and necrotic cells. Different concentrations of DNC $(15,17.5$, and $20 \mu \mathrm{M}$ ) were subjected to U87MG after 12, 24, and 36 hours of treatment. As indicated in Figure 9A, DNC induced apoptosis in a time- and dose-dependent manner. Percentages of early apoptosis after 12, 24, and 36 hours of treatment with $17.5 \mu \mathrm{M}$ were determined as $26.09 \% \pm 0.007 \%$, $30.2 \% \pm 0.02 \%$, and $34.75 \% \pm 0 \%$, respectively $(P=0.02)$. 
A

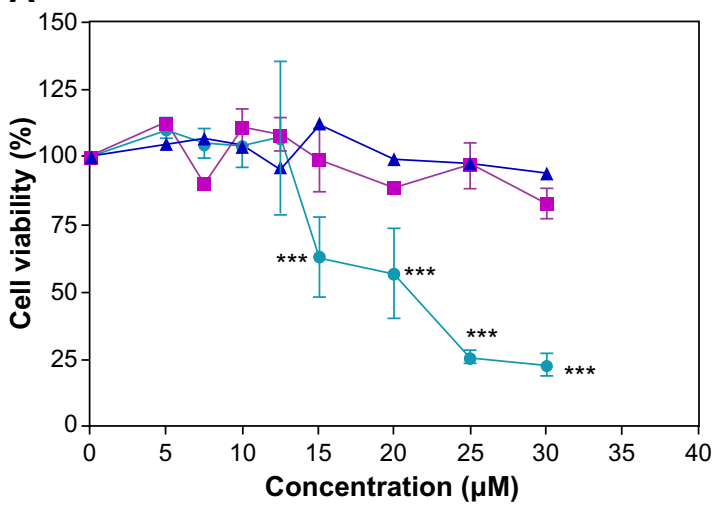

B

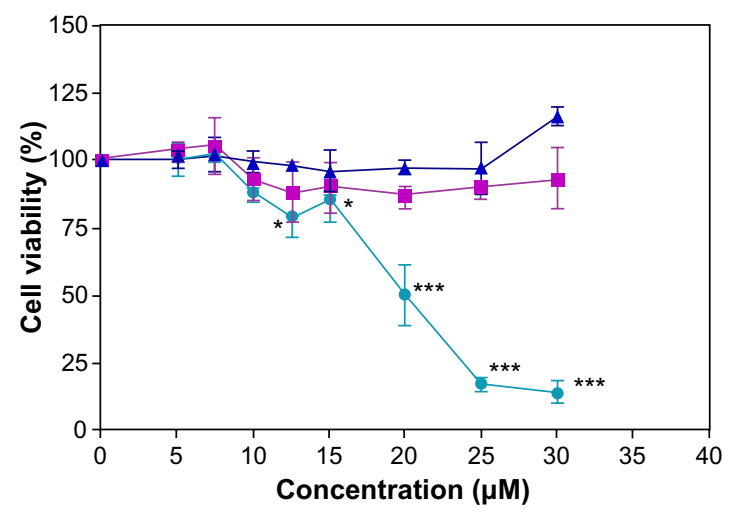

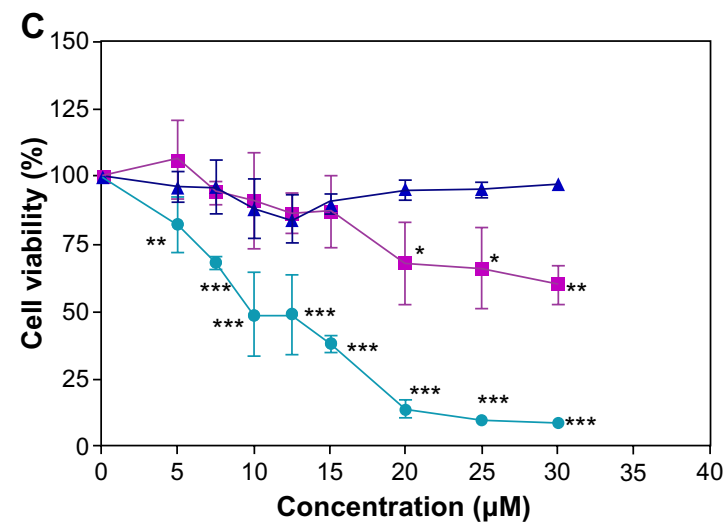

Figure 4 Effects of dendrosomal curcumin, free curcumin, and empty dendrosome on the viability of U87MG cells. Cells were treated with different concentrations of each agent for (A) 24, (B) 48, and (C) 72 hours.

Notes: Data expressed as mean \pm standard deviation; $* P<0.05 ; * * P<0.0$ I; *** $P<0.00$ I compared to nontreated cells.

\section{Elevated rate of caspase activity in U87MG} after DNC treatment

The potential of DNC to activate caspase during apoptosis was determined in a time- and dose-dependent manner. Different concentrations of DNC $(15,17.5$, and $20 \mu \mathrm{M})$ were subjected to U87MG after 12, 24, and 36 hours of treatment. As illustrated in Figure 9B, DNC induced caspase activation in a time-dependent behavior. Treatment with $17.5 \mu \mathrm{M}$ DNC resulted in $1.32 \pm 0.08$-fold, $2.34 \pm 0.1$-fold, and 3.49 \pm 0.009 -fold elevated caspase activity in U87MG cells after 12, 24, and 36 hours of exposure, respectively $(P<0.0001)$.

DNC inhibits U87MG cells by silencing the expression of pluripotency transcription factors including OCT4A, OCT4BI, SOX-2, and Nanog Real-time PCR was used to study the effect of DNC on the expression of pluripotency genes including OCT4A
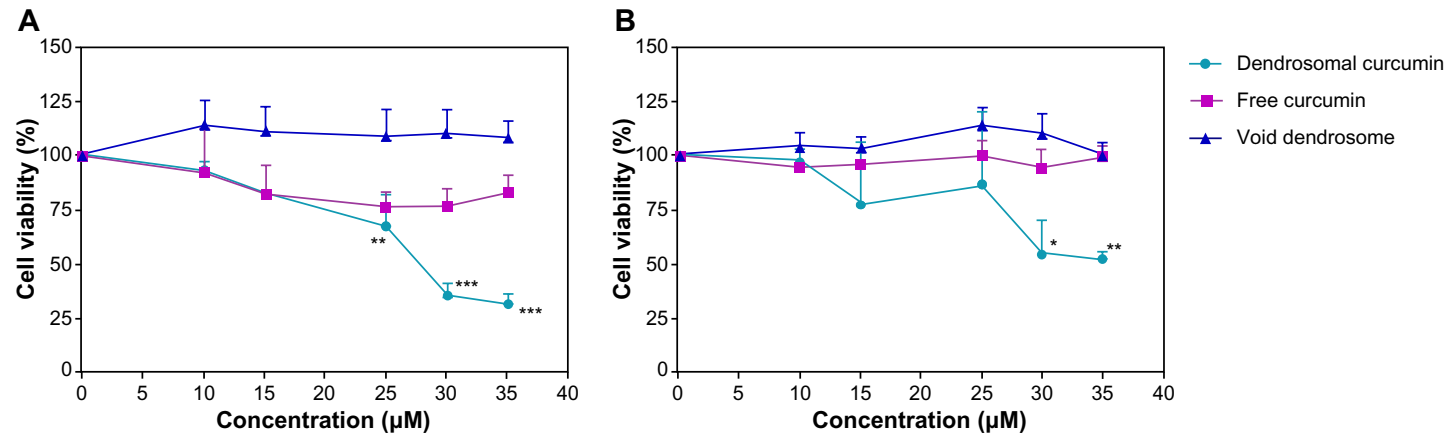

Figure 5 Effects of dendrosomal curcumin, free curcumin, and empty dendrosome on the viability of human bone marrow-derived stem cells. Cells were treated with different concentrations of each agent for (A) 24 and (B) 48 hours.

Notes: Data expressed as mean \pm standard deviation; $* P<0.05 ; * * P<0.01 ; * * * P<0.00$ I compared to nontreated cells. 


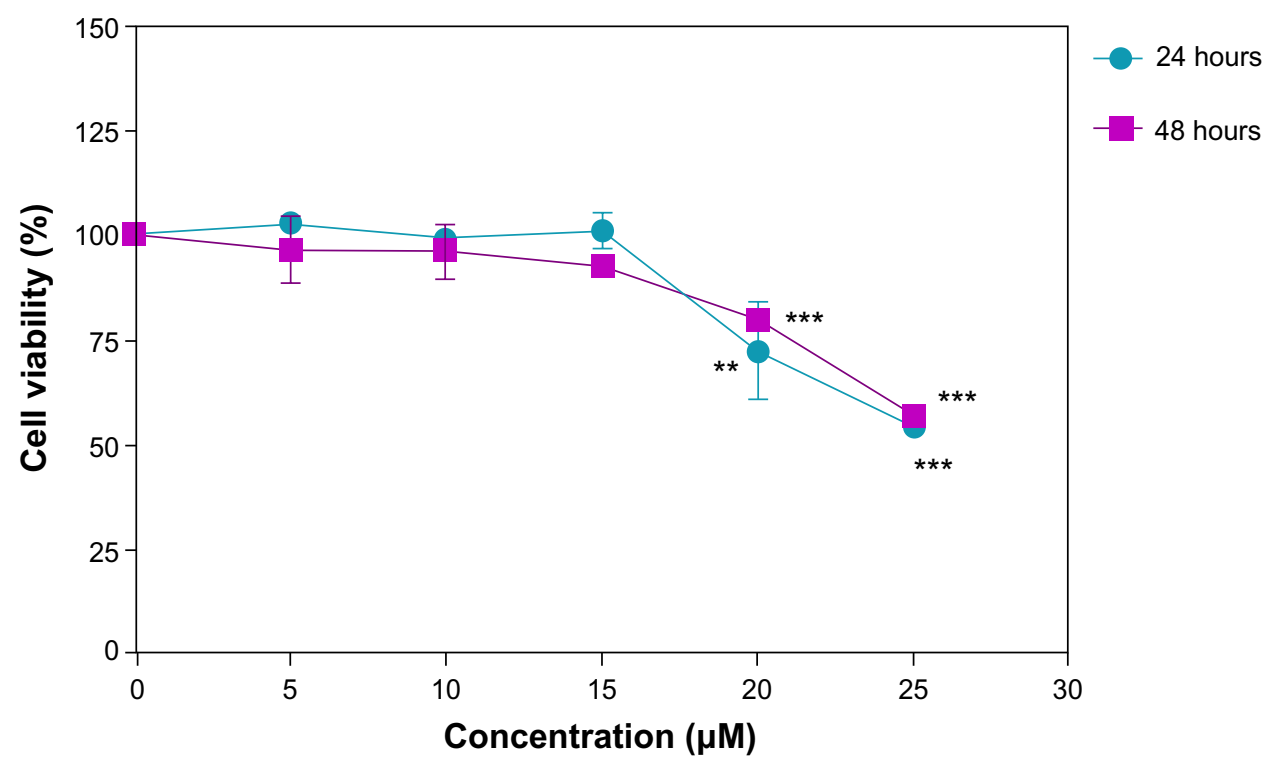

Figure 6 Effects of dendrosomal curcumin on the viability of HFSF-PI3 cells. Cells were treated with various concentrations of dendrosomal curcumin for 24 and 48 hours. Notes: Data expressed as mean \pm standard deviation; $* * P<0.0$ I; $* * * P<0.00$ I compared to nontreated cells.

variants $(A, B$, and $B 1), S O X-2$, and Nanog after treatment with $17.5 \mu \mathrm{M}$ DNC at 12,24 , and 36 hours post-treatment. Designed OCT4 primer sets are potent to discriminate between all OCT4 variants and related pseudogenes. In normal culture conditions, the OCT4A variant is weakly expressed in $\mathrm{U} 87 \mathrm{MG}$ and negative expression was observed for the $O C T 4 B$ variant but $O C T 4 B 1, S O X-2$, and Nanog were noticeably expressed in U87MG, suggesting that these genes are more important for proliferation in U87MG cells. As shown in Figure 10A, expression of the
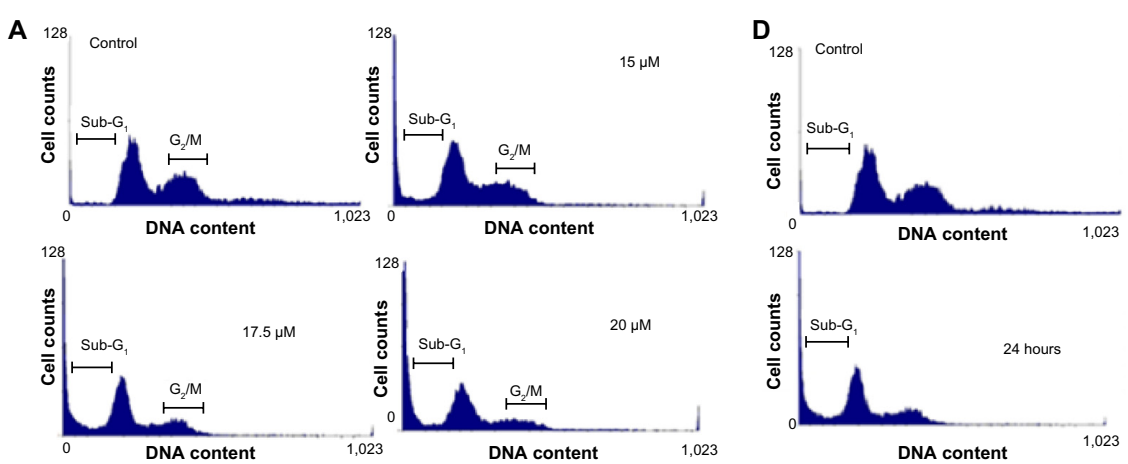

DNA content
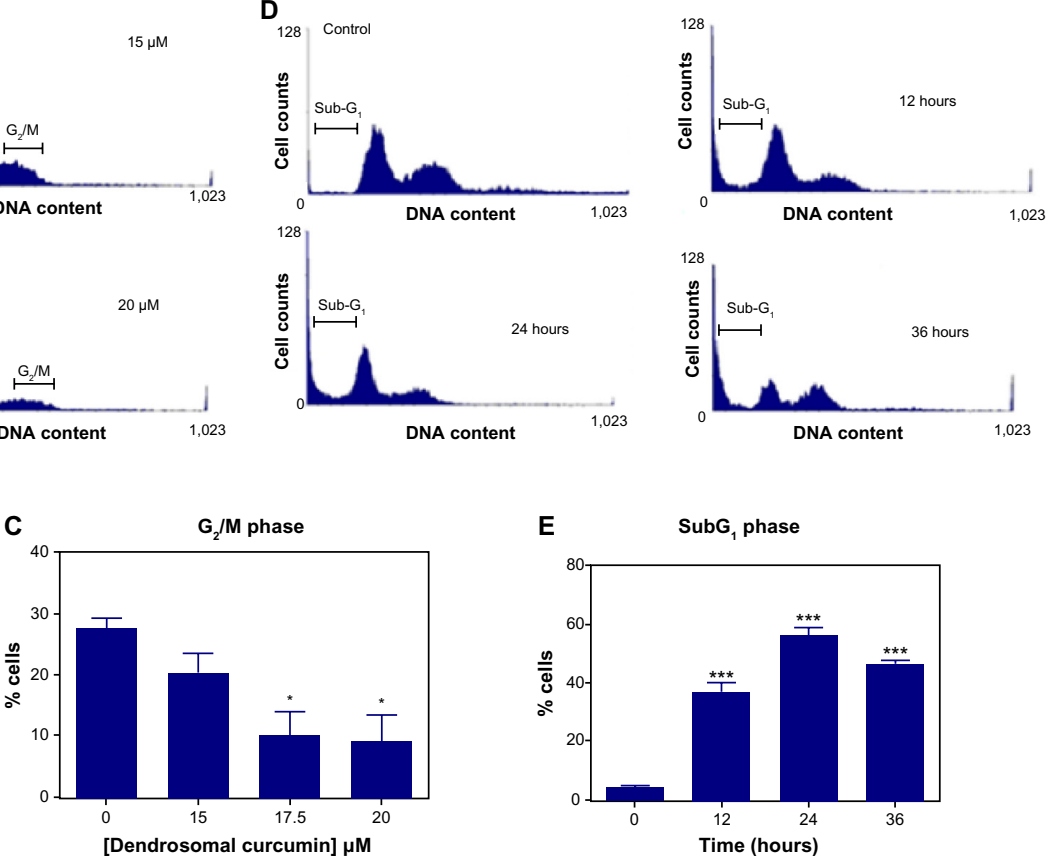

E

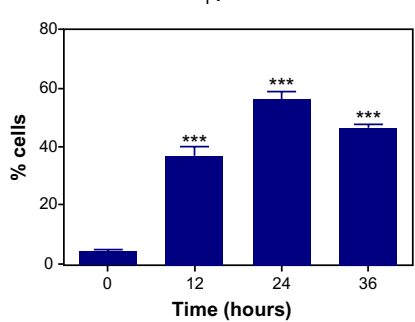

Figure 7 Flow cytometric analysis of the cell cycle in U87MG cells after dose- and time-dependent treatment with dendrosomal curcumin. (A) The cell counts upon treatment with 15, 17.5, and $20 \mu \mathrm{M}$ dendrosomal curcumin after 24 hours of treatment resulted in the appearance of the SubG, peak in comparison with control cells. (B) The percentage of cells in the SubG phase at different concentrations of dendrosomal curcumin after 24 hours of treatment. (C) The percentage of cells in the $G_{2} / M_{\text {phase at }}$ different concentrations of dendrosomal curcumin after 24 hours of treatment. (D) The cell counts upon treatment after 12, 24, and 36 hours of treatment with dendrosomal curcumin. (E) The percentage of cells in the SubG, phase at different incubation times with dendrosomal curcumin.

Notes: Data expressed as mean \pm standard deviation; $* P<0.05$; $* * * P<0.001$ compared to control. 
Table 2 Cell cycle distribution in U87MG cells after 24-hour dose-dependent treatment of the cells with dendrosomal curcumin using flow cytometry analysis

\begin{tabular}{lcccr}
\hline DNC $(\mu M)$ & Cell phase & & & \\
\cline { 2 - 5 } & SubG $(\%)$ & $\mathbf{G}_{1}(\%)$ & S (\%) & $\mathbf{G}_{2} / \mathbf{M}(\%)$ \\
\hline 0 & $3.99 \pm 0.004$ & $39.35 \pm 0.005$ & $10 \pm 0.04$ & $27.45 \pm 0.01$ \\
15 & $27.05 \pm 0.004$ & $32.18 \pm 0.06$ & $8.49 \pm 0.008$ & $20.28 \pm 0.03$ \\
17.5 & $56 \pm 0.02$ & $27 \pm 0.006$ & $6 \pm 0.03$ & $10 \pm 0.04$ \\
20 & $57.62 \pm 0.07$ & $26.61 \pm 0.02$ & $3.95 \pm 0.001$ & $8.92 \pm 0.1$ \\
\hline
\end{tabular}

Note: Data expressed as mean \pm standard deviation.

Abbreviation: DNC, dendrosomal curcumin.

$O C T 4 A$ variant $(P<0.0001), O C T 4 B 1$ variant $(P=0.0048)$, SOX-2 $(P<0.0001)$, and Nanog $(P=0.007)$ significantly decreased after 36 hours of treatment with $17.5 \mu \mathrm{M}$ DNC.

\section{DNC activated miR-I 45 expression in U87MG cells}

The effect of DNC on the expression of miR-145 was investigated. $m i R-145$ is related to the suppression of genes implicated in pluripotency (OCT4 and SOX-2). An increased level of $m i R-145$ can be observed during differentiation. An effect of DNC on miR-145 expression was examined after 24 hours of treatment with $17.5 \mu \mathrm{M}$ DNC. As shown in Figure 10B, miR-145 expression was elevated approximately 34.35 \pm 3.9 -fold in comparison with nontreated control cells $(P=0.005)$. The results show that DNC decreased the expression of OCT4A, OCT4B1, and SOX-2 in an miR-145dependent manner.

\section{Discussion}

Glioblastoma is one of the most invasive and heterogenic primary tumors in the central nervous system, with an average survival rate of 1 year. Tumor resection combined with radio- and chemotherapy is the current strategy to treat patients with glioblastoma. The lack of clear margin in glioma tumors results in incomplete resection and tumor recurrence. Additionally, the blood-brain barrier prevents the diffusion of large hydrophobic and ionic molecules to the tumor, making the use of systemically delivered drugs poorly effective. The injection of therapeutic agents into a surgically resected tumor or transient disruption of the blood-brain barrier is a technique suggested to bypass such shortcomings. ${ }^{28,29} \mathrm{In}$ spite of the clinical and technical progress in glioblastoma therapy, the mortality rate of this tumor remains high. ${ }^{30} \mathrm{At}$ present, the increasing knowledge of nanotechnology promises to be helpful in the development of localized delivery of therapeutic agents by means of nanocarriers with small particle size. ${ }^{31}$ Here, curcumin was efficiently encapsulated in dendrosome micellar structures. The pleiotropic features of curcumin to affect multiple signaling pathways and its preferential targeting of cancer cells rather than normal cells makes it an attractive agent for cancer therapy, ${ }^{32,33}$ and it is safe even at high doses. ${ }^{34}$ Given the well-known limitations of glioblastoma treatment strategies, the role of DNC on the proliferation of U87MG - a cellular model of grade IV glioblastoma - was evaluated. The oncogenic characteristics of pluripotency factors including OCT4, SOX-2, and Nanog in glioma cells has been previously reported, feeding into formation of the idea that targeting pluripotency genes may represent a novel approach to providing better treatment for this type of cancer. ${ }^{2,5,7,8}$ Here, the expression of two OCT4 variants $(A$ and $B), S O X-2$, and Nanog, as markers of stemness after treatment with DNC, was measured. Moreover,
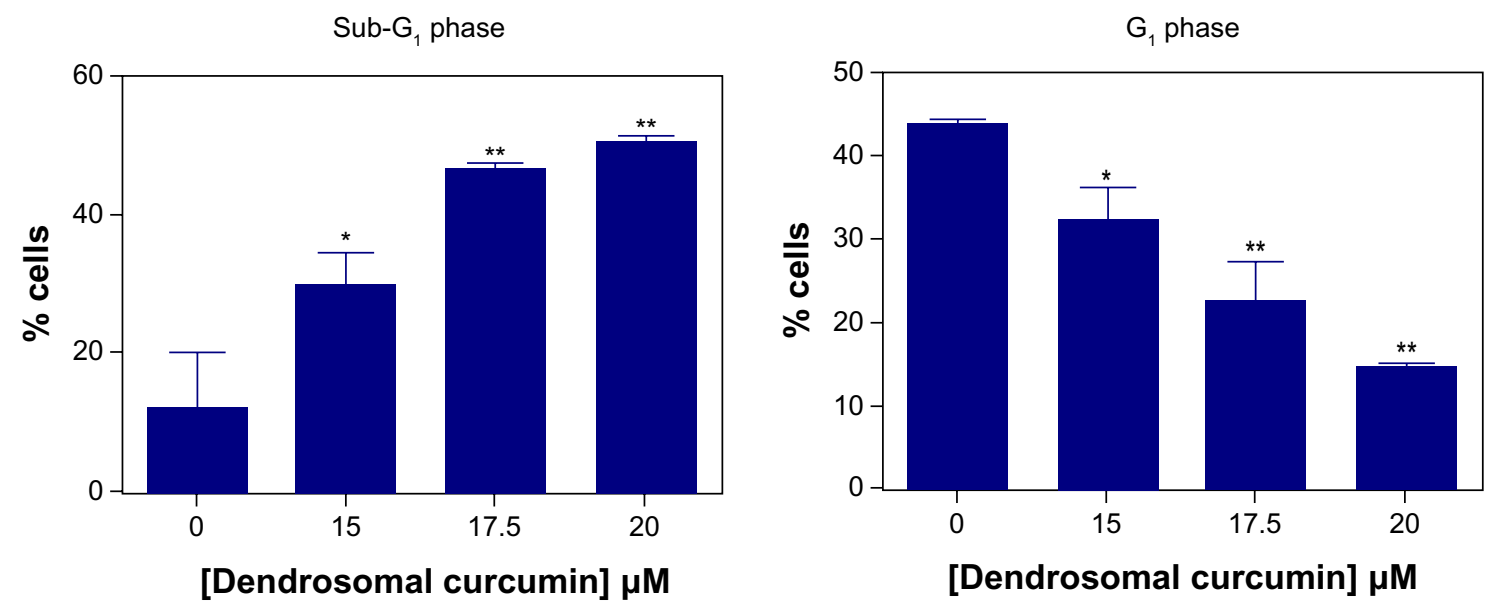

Figure 8 Flow cytometric analysis of cell cycle in U87MG cells after dose-dependent treatment with dendrosomal curcumin. The cell counts upon treatment with I5, I7.5, and $20 \mu \mathrm{M}$ dendrosomal after 36 hours of treatment resulted in the appearance of the SubG, peak in comparison with control cells. The graphs show the percentage of cells in the SubG, and $G_{1}$ phase at different concentrations of dendrosomal curcumin after 36 hours of treatment.

Notes: Data expressed as mean \pm standard deviation; $* P<0.05 ; * * P<0.0$ I compared to control. 
Table 3 Cell cycle distribution in U87MG cells after timedependent treatment of the cells with $17.5 \mu \mathrm{M}$ dendrosomal curcumin using flow cytometry analysis

\begin{tabular}{llllc}
\hline Cell phase & $\mathbf{t}=\mathbf{0}$ & $\mathbf{t}=\mathbf{|} \mathbf{2}$ hours & $\mathbf{t}=\mathbf{2 4}$ hours & $\mathbf{t}=\mathbf{3 6}$ hours \\
\hline SubG $(\%)$ & $3.9 \pm 0.004$ & $37 \pm 0.03$ & $56 \pm 0.02$ & $47 \pm 0.007$ \\
$\mathrm{G}_{1}(\%)$ & $39.35 \pm 0.005$ & $44 \pm 0.1$ & $27 \pm 0.006$ & $22 \pm 0.004$ \\
$\mathrm{~S}(\%)$ & $10.09 \pm 0.03$ & $6 \pm 0.02$ & $6 \pm 0.03$ & $7 \pm 0.02$ \\
$\mathrm{G}_{2} / \mathrm{M}(\%)$ & $27.45 \pm 0.01$ & 11.75 & $10 \pm 0.03$ & $19 \pm 0.01$ \\
\hline
\end{tabular}

Note: Data expressed as mean \pm standard deviation.

Abbreviation: $t$, time.

OCT4B1, a novel variant of OCT4 formerly demonstrated by the authors' research group as a gene involved in the pluripotency pathway, ${ }^{35}$ was evaluated. However, the oncogenic roles of OCT4 as a result of related pseudogenes are still controversial. ${ }^{36-38}$ Most of this controversy regarding OCT4 expression is related to OCT4A, which has a strong similarity to OCT4 pseudogenes. The OCT4 primer sets used in the present study are effective in discriminating between all OCT4 variants and related pseudogenes. ${ }^{35}$

In vitro characterization of DNC confirmed that dendrosomes have efficiently encapsulated curcumin in
$142 \mathrm{~nm}$ spherical structures, which makes it suitable for systemic administration. Analysis of the physical and chemical stability confirmed that DNC has a constant diameter and drug content even 16 days after preparation of this formulation. Data from both MTT assay and flow cytometry show that DNC induced cell death in U87MG cells in a time- and dose-dependent manner, significantly increasing the $\mathrm{SubG}_{1}$ fraction and reducing the cell population in $\mathrm{G}_{2} / \mathrm{M}$. Together, these data indicate that $\mathrm{DNC}$ targets the proliferation pathways in U87MG cells. After 36 hours of exposure the $G_{1}$ phase fraction was reduced and the SubG $\mathrm{G}_{1}$ peak was increased, indicating that U87MG growth was inhibited with longer exposure time. Of note, there was no cytotoxicity related to the empty dendrosome in U87MG cells. The effects of DNC in both hBMSC and HFSF-PI3 cells were also examined to explore the possible cytotoxic effects on nonneoplastic cells. Calculation of the $\mathrm{IC}_{50}$ values in these cells clearly indicates that cell death occurs in a concentration higher than the one effective in cancer cells. These results may also indicate DNC has preferential uptake in cancer cells relative to normal cells,
A
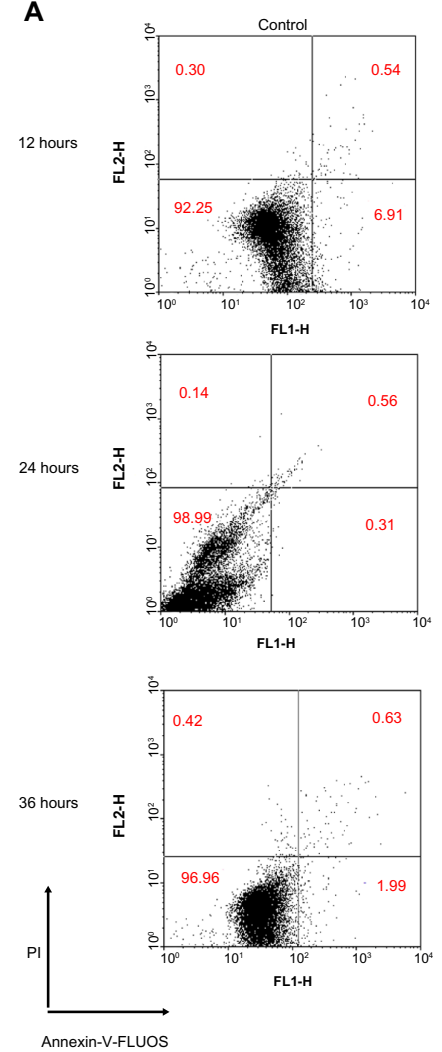
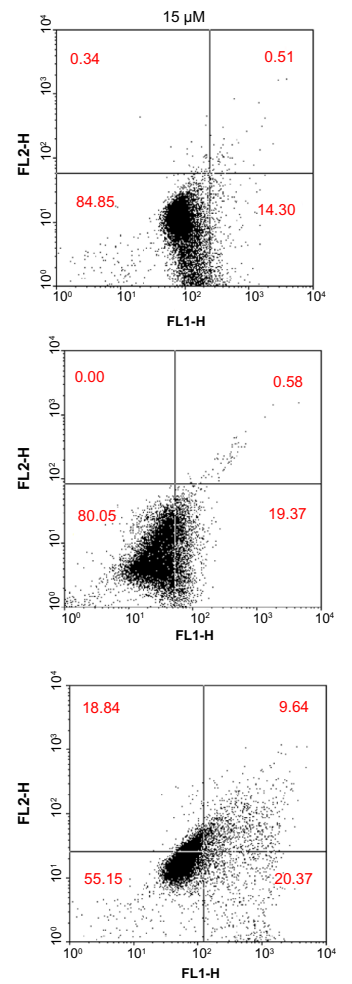
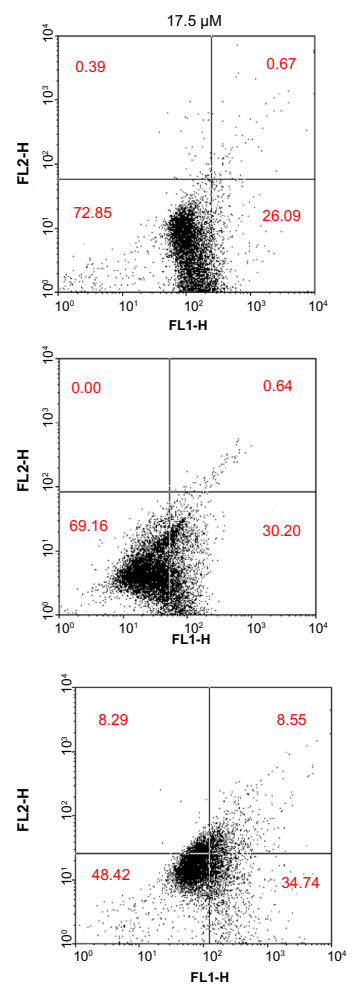

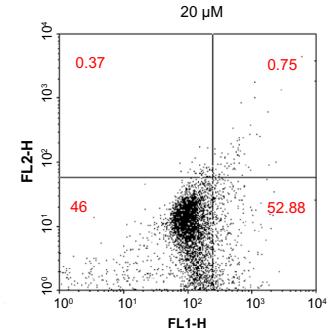

B

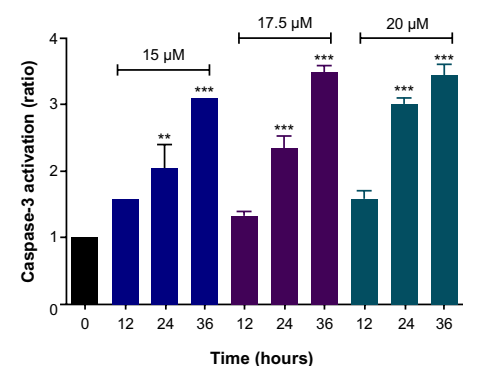

Figure 9 (A) Dendrosomal curcumin-induced apoptosis using Annexin-V-FLUOS/propidium iodide (PI) staining in U87MG cells. Viable cells (Annexin-V-/PI-), early apoptotic cells (Annexin- $\mathrm{V}+/ \mathrm{PI}-$ ), late apoptotic cells (Annexin- $\mathrm{V}-/ \mathrm{PI}+$ ), and necrotic cells (Annexin- $\mathrm{V}+/ \mathrm{PI}+$ ) are located in the lower left, lower right, upper right, and upper left quadrants, respectively. Numbers in each quadrant represent the percentage of cells. (B) Caspase-3 activation after treatment with various concentrations of dendrosomal curcumin and different incubation times.

Notes: Data expressed as mean \pm standard deviation; $* * P<0.0$ I; $* * * P<0.001$ compared to control. 
A

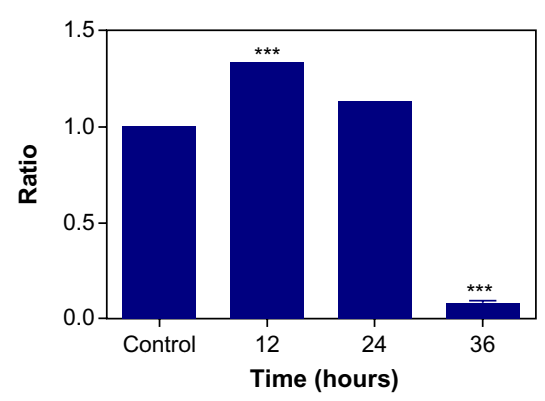

SOX-2

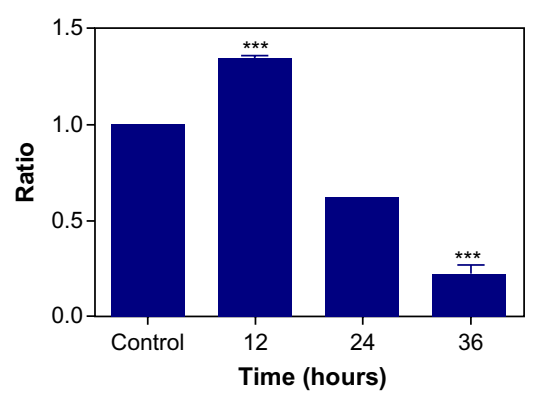

OCT4B1
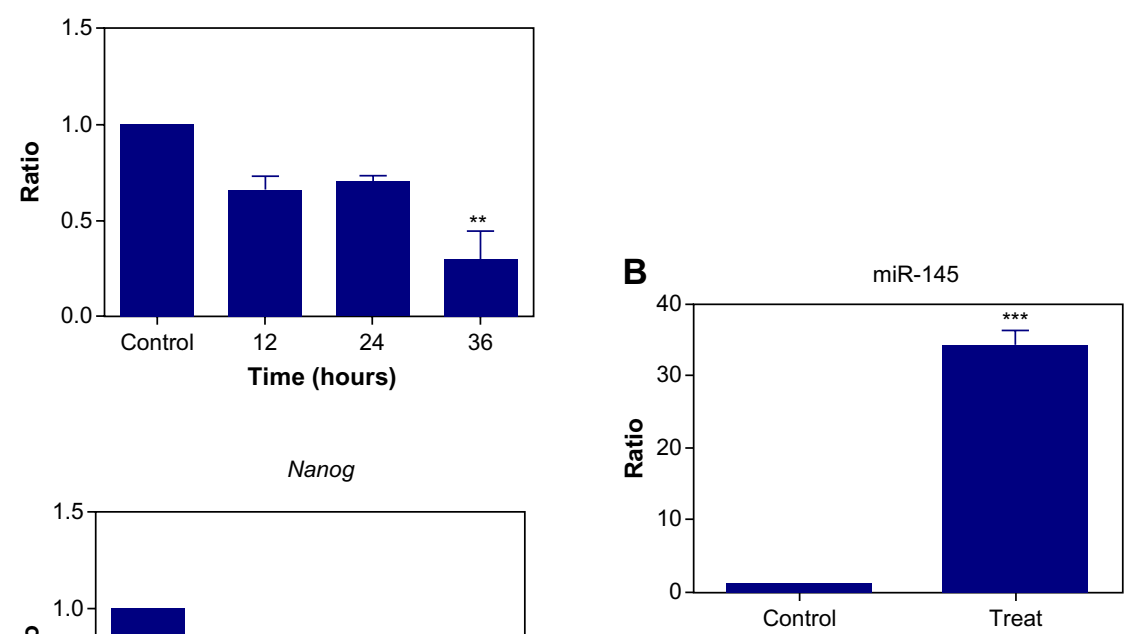

Figure 10 (A) Effects of dendrosomal curcumin on suppressing pluripotency genes (OCT4A, OCT4BI, SOX-2, and Nanog) after treatment with I7.5 $\mu$ M dendrosomal curcumin after 12, 24, and 36 hours of treatment. (B) Effects of dendrosomal curcumin on the upregulation of miR-/45 after 24-hour treatment with I7.5 $\mu$ M dendrosomal curcumin. Notes: Data expressed as mean \pm standard deviation; $* * P<0.0$ I; $* * * P<0.00$ I compared to control.

as previously mentioned. Protein composition as well as membrane structure diversity between tumor and normal cells could be responsible for drug sensitivity. ${ }^{23,32,39}$ Additionally, DNC can be considered a safe formulation for cancer therapy and clinical applications. Apoptosis depends on caspase activation, ${ }^{40}$ and the role of curcumin in inducing this biologic effect has been investigated in numerous studies that demonstrated its potential to activate different pathways related to apoptosis. ${ }^{41,42}$ In the present study, it was found that DNC-induced cell death in U87MG and was compatible with activation of the apoptotic pathway in a time- and dose-dependent manner. Accordingly, caspase-3 activation was increased by DNC. Previous studies reported that the induction of caspase- 3 by curcumin in glioma cells may involve histone hypoacetylation ${ }^{43}$ and activation of the tumor necrosis factor-related apoptosis-inducing ligand (TRAIL/Apo2L) pathway. ${ }^{44}$ Formerly, the role of DNC in apoptosis induction was reported in A431 cells - a cell line model of epidermoid carcinoma - in a PARP (poly [adenosine diphosphate ribose] polymerase-dependent) pathway, indicating that DNC induces cancer cell death via triggering of the apoptosis pathways. ${ }^{23}$ The present study also demonstrates that DNC reduces the expression of stemness genes including OCT4 variants, $S O X-2$, and Nanog, an action that may limit carcinogenesis. Although
Guo et al previously reported that there is a positive correlation between the expression level of OCT4A, SOX-2, and Nanog in glioma and tumor malignancy in a gradedependent fashion, ${ }^{45}$ this is the first report showing that curcumin has an inhibitory role on OCT4, SOX-2, and Nanog pluripotency genes.

The function of miRNAs as regulators of genes involved in cell growth and proliferation is well established. Among these, $m i R-145$ is one of the best characterized miRNAs in regulation of $O C T 4, S O X-2$, and $K L F-4$ pluripotency genes. For the first time, $\mathrm{Xu}$ et al proved that $m i R-145$ directly targets OCT4 and SOX-2 3'UTR. ${ }^{9}$ Downregulation of $m i R-145$ in a wide range of tumors suggested that this miRNA acts as a tumor suppressor. ${ }^{11}$

In the present study, miR-145 levels were markedly elevated after treatment with DNC, compatible with the hypothesis that repression of OCT4 and $S O X-2$ is due to the upregulation of miR-145. Lee et al previously showed that overexpression of $m i R-145$ can significantly inhibit migration and invasion of U87MG/U373MG cells. ${ }^{46}$ Although negative regulation of $m i R-145$ on OCT4 and $S O X-2$ has been demonstrated in glioma CD133 (+) cells, ${ }^{47}$ the present study shows for the first time that inhibition of OCT4 and $S O X-2$ by curcumin may occur through $m i R-145$ overexpression. Therefore, miRNA can 
be novel targets for natural chemopreventive agents as previously described. ${ }^{48}$

\section{Conclusion}

The novelty of this study is based on the effects of DNC on the pluripotency pathways of glioblastoma cells both at the level of gene expression and regulation. The data show that DNC efficiently suppresses glioblastoma cell growth by downregulation of pluripotency genes, possibly in an miRNA-dependent manner. These results indicate that miRNAs may be used as possible targets for cancer therapy. On the other hand, the lack of DNC cytotoxicity in mesenchymal and fibroblast cells indicates that this new nanodrug can be considered a safe formulation to induce cancer cell death using a natural compound.

\section{Acknowledgments}

This project was supported by grants from the School of Biological Sciences, Tarbiat Modares University, Tehran, Iran and the Department of Chemistry, Building of Pharmaceutical Sciences, University of Florence, Florence, Italy. The authors gratefully acknowledge these research departments for their sincere support offered during the project. The authors are thankful to their coworkers in the Cell and Molecular Laboratory of Tehran University for their support in performing flow cytometry analysis. The authors are so thankful to their colleague at Tarbiat Modares University, Mrs Shima Nazem, for her kind help in stem cell-related experiments. The authors would also like to express their special thanks to Professor Fabio Marra and Mr Babak Bakhshinejad for their generous assistance in manuscript preparation. The current work is dedicated to the late Professor Mohammad Nabi Sarbolouki who was a pioneer of dendrosome-based delivery of curcumin.

\section{Disclosure}

The authors report no conflicts of interest in this work. All the authors have read the manuscript and approved this submission to the International Journal of Nanomedicine.

\section{References}

1. Holland EC. Glioblastoma multiforme: the terminator. Proc Natl Acad Sci U S A. 2000;97(12):6242-6244.

2. Du Z, Jia D, Liu S, et al. Oct4 is expressed in human gliomas and promotes colony formation in glioma cells. Glia. 2009;57(7):724-733.

3. Dell'Albani P. Stem cell markers in gliomas. Neurochem Res. 2008;33(12):2407-2415.

4. Alves TR, Lima FR, Kahn SA, et al. Glioblastoma cells: a heterogeneous and fatal tumor interacting with the parenchyma. Life Sci. 2011;89(15-16):532-539.

5. Jordan CT. Cancer stem cell biology: from leukemia to solid tumors. Curr Opin Cell Biol. 2004;16(6):708-712.
6. Kashyap V, Rezende NC, Scotland KB, et al. Regulation of stem cell pluripotency and differentiation involves a mutual regulatory circuit of the NANOG, OCT4, and SOX2 pluripotency transcription factors with polycomb repressive complexes and stem cell microRNAs. Stem Cells Dev. 2009;18(7): 1093-1108.

7. Holmberg J, He X, Peredo I, et al. Activation of neural and pluripotent stem cell signatures correlates with increased malignancy in human glioma. PLoS One. 2011;6(3):e18454.

8. Annovazzi L, Mellai M, Caldera V, Valente G, Schiffer D. SOX2 expression and amplification in gliomas and glioma cell lines. Cancer Genomics Proteomics. 2011;8(3):139-147.

9. Xu N, Papagiannakopoulos T, Pan GJ, Thomson JA, Kosik KS. MicroRNA145 regulates OCT4, SOX2, and KLF4 and represses pluripotency in human embryonic stem cells. Cell. 2009;137(4):647-658.

10. Chivukula RR, Mendell JT. Abate and switch: miR-145 in stem cell differentiation. Cell. 2009;137(4):606-608.

11. Sachdeva M, Mo YY. miR-145-mediated suppression of cell growth, invasion and metastasis. Am J Transl Res. 2010;2(2):170-180.

12. Anand P, Sundaram C, Jhurani S, Kunnumakkara AB, Aggarwal BB Curcumin and cancer: an "old-age" disease with an "age-old" solution. Cancer Lett. 2008;267(1):133-164.

13. Lopez-Lazaro M. Anticancer and carcinogenic properties of curcumin: considerations for its clinical development as a cancer chemopreventive and chemotherapeutic agent. Mol Nutr Food Res. 2008;52(Suppl 1): S103-S127.

14. Salvioli S, Sikora E, Cooper EL, Franceschi C. Curcumin in cell death processes: a challenge for CAM of age-related pathologies. Evid Based Complement Alternat Med. 2007;4(2):181-190.

15. Subramaniam D, May R, Sureban SM, et al. Diphenyl difluoroketone: a curcumin derivative with potent in vivo anticancer activity. Cancer Res. 2008;68(6):1962-1969.

16. Anand P, Kunnumakkara AB, Newman RA, Aggarwal BB. Bioavailability of curcumin: problems and promises. Mol Pharm. 2007;4(6): 807-818.

17. Ferrari E, Pignedoli F, Imbriano C, et al. Newly synthesized curcumin derivatives: crosstalk between chemico-physical properties and biological activity. J Med Chem. 2011;54(23):8066-8077.

18. Orr WS, Denbo JW, Saab KR, et al. Liposome-encapsulated curcumin suppresses neuroblastoma growth through nuclear factor-kappa B inhibition. Surgery. 2012;151(5):736-744.

19. Kushwaha SKS, Rastogl A, Rai AK, Singh S. Novel drug delivery system for anticancer drug: a review. International Journal of PharmTech Research. 2012;4(2):542-553.

20. Anand P, Thomas SG, Kunnumakkara AB, et al. Biological activities of curcumin and its analogues (Congeners) made by man and mother nature. Biochem Pharmacol. 2008;76(11):1590-1611.

21. Sadeghizadeh M, Ranjbar B, Damaghi M, et al. Dendrosomes as novel gene porters-III. J Chem Technol Biotechnol. 2008;83(6): 912-920.

22. Sarbolouki MN, Sadeghizadeh M, Yaghoobi MM, Karami A, Lohrasbi T. Dendrosomes: a novel family of vehicles for transfection and therapy. J Chem Technol Biotechnol. 2000;75(10):919-922.

23. Babaei E, Sadeghizadeh M, Hassan ZM, Feizi MAH, Najafi F, Hashemi SM. Dendrosomal curcumin significantly suppresses cancer cell proliferation in vitro and in vivo. Int Immunopharmacol. 2012;12(1):226-234.

24. Alizadeh AM, Khaniki M, Azizian S, Mohaghgheghi MA, Sadeghizadeh M, Najafi F. Chemoprevention of azoxymethane-initiated colon cancer in rat by using a novel polymeric nanocarrier-curcumin. Eur J Pharmacol. 2012;689(1-3):226-232.

25. Gou M, Men K, Shi H, et al. Curcumin-loaded biodegradable polymeric micelles for colon cancer therapy in vitro and in vivo. Nanoscale. 2011;3(4):1558-1567.

26. Sinico C, Caddeo C, Valenti D, Fadda AM, Bilia AR, Vincieri FF. Liposomes as carriers for verbascoside: stability and skin permeation studies. J Liposome Res. 2008;18(1):83-90. 
27. Isacchi B, Bergonzi MC, Grazioso M, et al. Artemisinin and artemisinin plus curcumin liposomal formulations: enhanced antimalarial efficacy against Plasmodium berghei-infected mice. Eur J Pharm Biopharm. 2012;80(3):528-534.

28. Lima FR, Kahn SA, Soletti R, et al. Glioblastoma: therapeutic challenges, what lies ahead. Biochim Biophys Acta. 2012;1826(2):338-349.

29. Nduom EK, Bouras A, Kaluzova M, Hadjipanayis CG. Nanotechnology applications for glioblastoma. Neurosurg Clin N Am. 2012;23(3): 439-449.

30. Reardon DA, Wen PY. Therapeutic advances in the treatment of glioblastoma: rationale and potential role of targeted agents. Oncologist. 2006;11(2):152-164.

31. Invernici G, Cristini S, Alessandri G, et al. Nanotechnology advances in brain tumors: the state of the art. Recent Pat Anticancer Drug Discov. 2011;6(1):58-69.

32. Kunwar A, Barik A, Mishra B, Rathinasamy K, Pandey R, Priyadarsini KI. Quantitative cellular uptake, localization and cytotoxicity of curcumin in normal and tumor cells. Biochim Biophys Acta. 2008;1780(4): 673-679.

33. Hatcher H, Planalp R, Cho J, Torti FM, Torti SV. Curcumin: from ancient medicine to current clinical trials. Cell Mol Life Sci. 2008;65(11): 1631-1652.

34. Epstein J, Sanderson IR, Macdonald TT. Curcumin as a therapeutic agent: the evidence from in vitro, animal and human studies. Br J Nutr. 2010;103(11):1545-1557.

35. AtlasiY, Mowla SJ, Ziaee SAM, Gokhale PJ, Andrews PW. OCT4 spliced variants are differentially expressed in human pluripotent and nonpluripotent cells. Stem Cells. 2008;26(12):3068-3074.

36. Zhao S, Yuan Q, Hao H, et al. Expression of OCT4 pseudogenes in human tumours: lessons from glioma and breast carcinoma. J Pathol. 2011;223(5):672-682.

37. Suo G, Han J, Wang X, et al. Oct4 pseudogenes are transcribed in cancers. Biochem Biophys Res Commun. 2005;337(4):1047-1051.

38. Liedtke S, Enczmann J, Waclawczyk S, Wernet P, Kogler G. Oct4 and its pseudogenes confuse stem cell research. Cell Stem Cell. 2007;1(4): $364-366$.
39. Kong Y, Ma W, Liu X, et al. Cytotoxic activity of curcumin towards CCRF-CEM leukemia cells and its effect on DNA damage. Molecules. 2009; 14(12):5328-5338.

40. Sattar R, Ali SA, Abbasi A. Molecular mechanism of apoptosis: prediction of three-dimensional structure of caspase- 6 and its interactions by homology modeling. Biochem Biophys Res Commun. 2003;308(3):497-504.

41. Karmakar S, Banik NL, Patel SJ, Ray SK. Curcumin activated both receptor-mediated and mitochondria-mediated proteolytic pathways for apoptosis in human glioblastoma T98G cells. Neurosci Lett. 2006;407(1):53-58.

42. Karmakar S, Banik NL, Ray SK. Curcumin suppressed anti-apoptotic signals and activated cysteine proteases for apoptosis in human malignant glioblastoma U87MG cells. Neurochem Res. 2007;32(12): 2103-2113.

43. Kang SK, Cha SH, Jeon HG. Curcumin-induced histone hypoacetylation enhances caspase-3-dependent glioma cell death and neurogenesis of neural progenitor cells. Stem Cells Dev. 2006;15(2):165-174.

44. Gao X, Deeb D, Jiang H, Liu YB, Dulchavsky SA, Gautam SC. Curcumin differentially sensitizes malignant glioma cells to TRAIL/ Apo2L-mediated apoptosis through activation of procaspases and release of cytochrome c from mitochondria. J Exp Ther Oncol. 2005;5(1):39-48

45. Guo Y, Liu S, Wang P, et al. Expression profile of embryonic stem cell-associated genes Oct4, Sox2 and Nanog in human gliomas. Histopathology. 2011;59(4):763-775.

46. Lee SJ, Kim SJ, Seo HH, et al. Over-expression of miR-145 enhances the effectiveness of HSVtk gene therapy for malignant glioma. Cancer Lett. 2012;320(1):72-80.

47. Yang YP, Chien Y, Chiou GY, et al. Inhibition of cancer stem celllike properties and reduced chemoradioresistance of glioblastoma using microRNA145 with cationic polyurethane-short branch PEI. Biomaterials. 2012;33(5):1462-1476.

48. Li Y, Kong D, Wang Z, Sarkar FH. Regulation of microRNAs by natural agents: an emerging field in chemoprevention and chemotherapy research. Pharm Res. 2010;27(6):1027-1041. 


\section{Supplementary material}

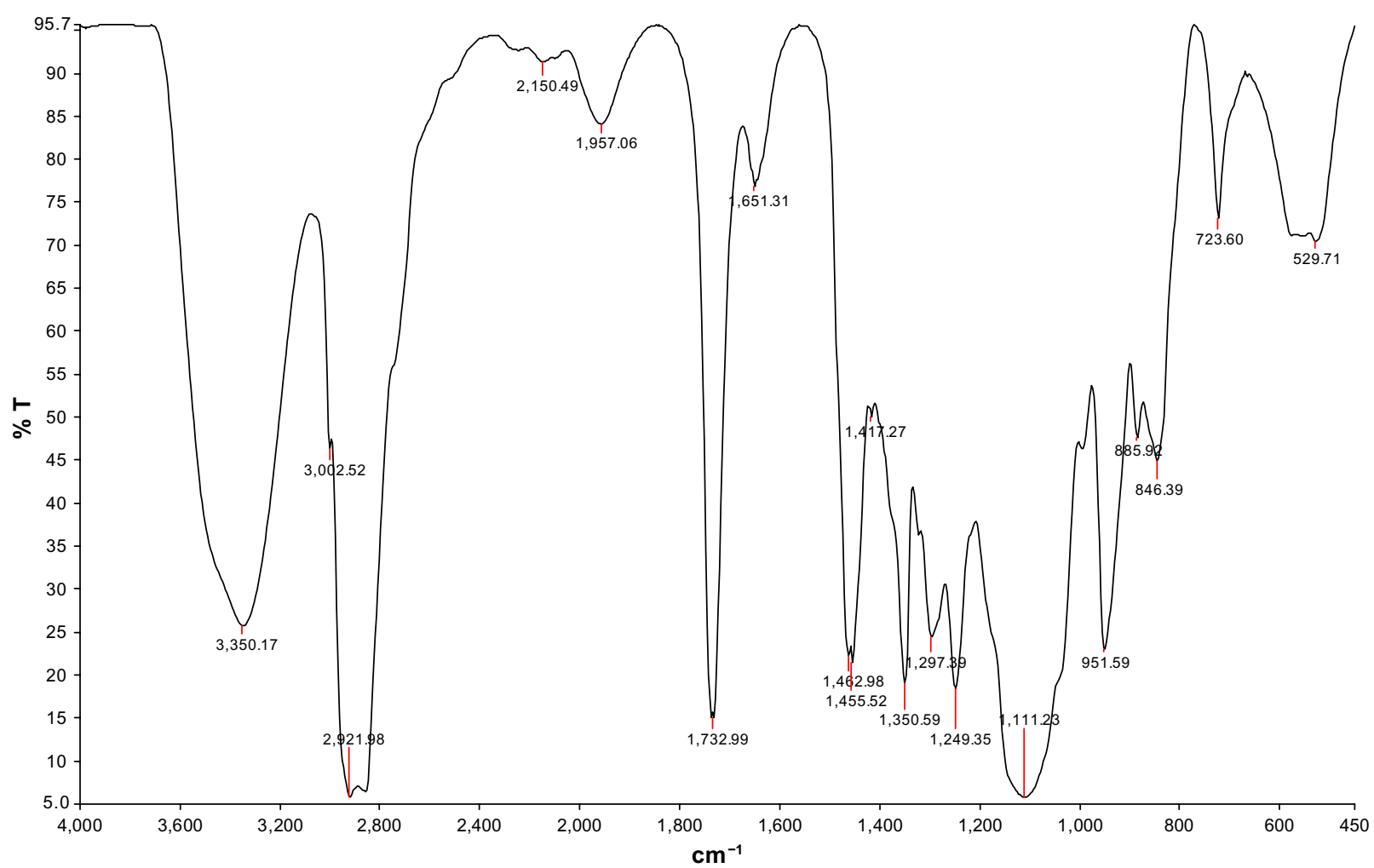

Figure SI The Fourier transform infrared spectrum of OA400 shows a stretching band of $\mathrm{C}-\mathrm{H}$ aliphatic at $2,92 \mathrm{I} \mathrm{cm}^{-1}$, a stretching band of $\mathrm{C}-\mathrm{H}$ unsaturated aliphatic at $3,002 \mathrm{~cm}^{-1}$, and a stretching band carbonyl group of ester bands at $\mathrm{I}, 732 \mathrm{~cm}^{-1}$. The $\mathrm{C}-\mathrm{H}$ bending vibration of $\mathrm{CH}_{2}$ and the $\mathrm{C}-\mathrm{H}$ bending vibration of $\mathrm{CH}_{3}$ can be seen at $\mathrm{I}, 462 \mathrm{~cm}^{-1}$ and $\mathrm{I}, 350 \mathrm{~cm}^{-1}$, respectively. The $\mathrm{C}-\mathrm{O}$ stretching vibration was at $\mathrm{I}, \mathrm{II} \mathrm{I} \mathrm{cm}^{-1}$ as a broad band. The $\mathrm{C}=\mathrm{C}$ stretching vibration can be seen at $\mathrm{I}, 65 \mathrm{I} \mathrm{cm}$.

\section{Publish your work in this journal}

The International Journal of Nanomedicine is an international, peerreviewed journal focusing on the application of nanotechnology in diagnostics, therapeutics, and drug delivery systems throughout the biomedical field. This journal is indexed on PubMed Central, MedLine, CAS, SciSearch ${ }^{\circledR}$, Current Contents ${ }^{\circledR} /$ Clinical Medicine,
Journal Citation Reports/Science Edition, EMBase, Scopus and the Elsevier Bibliographic databases. The manuscript management system is completely online and includes a very quick and fair peer-review system, which is all easy to use. Visit http://www.dovepress.com/ testimonials.php to read real quotes from published authors. 